\title{
EFFECT OF DIFFERENT FOOD ON DEVELOPMENT, REPRODUCTION AND SURVIVAL OF UROOBOVILLA KRANTZI ZAHER AND AFIFI (ACARINA: UROPODIDAE)
}

\author{
MOSTAFA, A.M. ${ }^{1}$, AMINA M. ABDEL-RAHMAN ${ }^{2}$, E. M. A. YASSIN ${ }^{1}$, \\ and RANIA H. SABER ${ }^{1}$
}

1. Plant Protection Research Institute, ARC, Dokki, Giza, Egypt

2. Entomology Dept, Fac. Sci., Cairo Univ., Giza, Egypt.

(Manuscript received 13 January 2013)

\begin{abstract}
The current study indicated that the type of tested nematode food and temperatures had slightly significantly difference on the incubation period of uropodid mite, Uroobovilla krantzi (both sexes) when fed on free living and parasitic nematodes. The longest incubation period durated 4.1 days when females fed on free nematodes at $15^{\circ} \mathrm{C}$, but the lowest one was 1.6 days at $35^{\circ} \mathrm{C}$ when males fed on parasitic nematodes. Whoever, the data indicated that the tested nematodes significantly affected on the mite life cycle.Also the study denoted that the type of food had very highly significant differences effects on male and female longevity. Eggs of mites were apparently produced only by fertilized females. Significantly more eggs were laid when mites fed on free nematodes at $35^{\circ} \mathrm{C}$. (132.2 eggs), but the lower eggs were observed when females fed on parasitic nematodea at $15^{\circ} \mathrm{C}$.
\end{abstract}

\section{INTRODUCTION}

Although the Acarina communities of Egyptian soil have not been widely studied, some information is available on the mesostigmatid mites fauna. Owing to their numerical importance, the gamasid mites have received more attention than other soil Acari. The majority of these species appear to predators associated with small and immature stages of insects, mites, and nematodes in the soil surface (Karg, 1961, Sardar and Murphy, 1987). Uropodids are free-living mites inhabiting soil. The feeding habits of most species of the family Uropodidae are unknown, but the family apparently includes feeders on such things as fungi, organic detritus, nematodes, and insect eggs and larvae (Krantz, 1978). Moreover, Radinovsky and Krantz (1961) and Radinovsky (1965) stated that some uropodids are fungivorous. In Egypt, some scattered studies dealt with the biology and feeding habits of certain uropodids (Afifi, 1980, El-Bishlawy and Afifi, 1982, Abou-El-Naga et. al., 1987, Abbassy et. al., 1991, Nawar et. al., 1993 and Mowafi 2005) .The present part of the work aimed to study the possible effects of free and parasitic nematodes on the biological aspects of the uropodid predaceous mite, U. krantzi, at different temperatures $\left(15,25\right.$ and $\left.35^{\circ} \mathrm{C}\right)$. 


\section{MATERIALS AND METHODS}

Collection and preparation of U. krantzi: Individuals belonging to the commonest species $U$. krantzi used in biological studies were collected from normal untreated soil of cotton and onion. Mass rearing of the free-living nematode was maintained in the laboratory. To rear the mite, there are two types of cages were used. The first for culturing mites (large glass Petri dishes filled up to $0.5 \mathrm{~cm}$ with a mixture of plaster of Paris and charcoal (9: 1) and the second for individual rearing (plastic ring $2.5 \mathrm{~cm}$ in diameter and $1.5 \mathrm{~cm}$ in depth) filled with $0.7 \mathrm{~cm}$ with a mixture of plaster of Paris and charcoal (7: 3) according to Metwally et. al., (1983). For culturing of mites, several adult females and males of mite, $U$. krantzi were placed in Petri-dishes and supplied with small glass slide to prevent mites escaping and repeat in an incubator at $25{ }^{\circ} \mathrm{C}$ and $70 \%$ R.H. The bottom was kept moist, thus the relative humidity was suitable by adding a few drops of water every two days. After hatching, each larva was supplied with free living nematodes as prey. Observations were made twice daily using stereomicroscope to determine different biological aspects. Source of food: Soil samples were put in Baerman funnel for 24 hours for extracting free living nematode, Abou-El-Sooud (1992).The extraction of free living nematode was rearing in Petri-dishes contains slides of Potatoes. Parasitic nematode (Root knot nematodes) Meloidogyne incognita (Kofoid and White) Chitwood, was obtained already from Plant Pathology Institute, Agricultural Research Center. Suitable statistical analysis was used to clearify the results of the work. All biological data were subjected to one and two ways analysis variance (ANOVA) and means were separated by Duncan's multiple range test, Duncan, (1955).

\section{RESULTS AND DISCUSSION}

In this study, the trials were conducted under laboratory conditions of $(15,25$ and $35 \pm 2{ }^{\circ} \mathrm{C}$ and relative humidity $75 \pm 5 \%$ R.H.) to study the effect of different prey on the biological aspects of the uropodid mite Uroobovilla krantzi.

\section{Biological aspects}

\section{A. Female}

\section{Incubation period}

It was clearly obvious from Table (1) that there was highly significant differences between the incubation period which give rise to females in case of the predacious mite $U$. krantzi when fed on different diets at different temperatures. This period was $(4.1,3.85),(3.33,2.77)$ and $(2.39,2.2)$ days when the male individuals fed on free and parasitic nematodes at 15,25 and $35^{\circ} \mathrm{C}$, respectively. However, statistical 
analysis of obtained data indicated that there were highly significant differences between the individuals reared at different temperatures and fed on different diets.

\section{Immature stages}

The tabulated data in Table (1) showed that the duration of immature stages of mite U. krantzi female was highly significantly differed according to the type of used food and tested temperature. The lowest period of the immature stages was recorded when the mites fed on parasitic nematodes at $35^{\circ} \mathrm{C}$. (9.31 days) increased to recorded the highest period (22.9 days) when the individuals fed on the free nematodes at $15^{\circ} \mathrm{C}$.

Life cycle: Concerning the life cycle of U. krantzi female Table (1), statistical analysis of current data pointed out that this period was highly significantly differed at different temperature degrees. The obtained results indicated that the highest duration period of the life cycle was recorded when the mites individuals fed at $15^{\circ} \mathrm{C}$ ( 28.3 days) when the females fed on free nematodes, while the lowest period was observed when the individuals fed on parasitic nematodes at $35^{\circ} \mathrm{C}$ (13.1 days).

\section{Longevity}

Concerning the adult longevity of $U$. krantzi female, Table (1), statistical analysis of obtained data pointed out that this period was significantly differed. It was $(86.5,75.2),(75.4,65.8)$ and $(69.8,64.0)$ days when mites reared on the free and parasitic nematodes at 15,25 and $35{ }^{\circ} \mathrm{C}$, respectively. However, the resulted data as shown in Table (2) showed that there were highly significant differences between the U. krantzi individuals fed on the free and parasitic nematodes at different temperature in case of periods of female longevity (preoviposition, oviposition and postoviposition). The preoviposition period lasted 3.5, 2.5, and 2.0 days when the individuals reared at 15,25 and $35{ }^{\circ} \mathrm{C}$, respectively on free nematodes changed to 3.0, 2.0 and 1.6 days when the mites fed on parasitic nematodes, respectively. However, female oviposition period lasted $(79.75,68.5),(72.25,62.5)$ and $(62.75$ and 58.5$)$ days when the female fed on free and parasitic nematodes at 15,25 and $35{ }^{\circ} \mathrm{C}$., respectively. On the other hand the postoviposition periods of female individuals lasted about $(3.25,2.4),(2.5$, 2.0) and (2.0 and 1.6) days, when the mite females reared at the same laboratory conditions, respectively.

\section{Life span}

Accordingly, the life span of the predatory mite, U. krantzi differed at different temperatures. However, this period lasted the highest period (115.0 days) when females fed on the free tested nematode at $15{ }^{\circ} \mathrm{C}$, changed to recorded the lowest level of duration when females reared at $35{ }^{\circ} \mathrm{C}$ (73.2 days) on parasitic nematodes, Table (1). 


\section{Fecundity}

Mating is essential for U. krantzi eggs deposition. Eggs production in $U$. krantzi is influenced by the type of food ingested, Table (2). Data clearly indicated that the feeding on free nematodes at $35^{\circ} \mathrm{C}$ gave the highest level of egg laying (132.2 eggs) while the laid number of eggs was 89.25 eggs, (the lowest number) when the mothers fed at $15^{\circ} \mathrm{C}$ on parasitic nematodes.

\section{B. Male}

\section{Incubation period}

As shown in Table (3) data revealed that there was highly significant difference between the incubation periods which gave rise to males of $U$. krantzi when fed on the two kinds of tested nematodes at different temperatures. This period was $3.74,3.49,3.02,2.59,2.09$ and 1.915 days when male individuals fed on free and parasitic nematodes at 15,25 and $35^{\circ} \mathrm{C}$, respectively.

\section{Immature stages}

The tabulated data in Table (3) indicated that the immature stages of the predatory mite $U$. krantzi male was differed when the tested temperature changed from 15 to $35^{\circ} \mathrm{C}$. when the individuals reared on free and parasitic nematodes. This period lasted $21.69,20.5,11.7,10.5,9.56$ and 8.84 days when the male individuals fed on free and parasitic nematodes at 15,25 and $35^{\circ} \mathrm{C}$, respectively.

\section{Life cycle}

Concerning the life cycle of $U$. krantzi males, Table (3), statistical analysis of obtained data cleared that this period was highly significantly differed at different temperatures. The highest duration period recorded when mite individuals reared at 15 ${ }^{\circ} \mathrm{C}$ (25.46 days) on free nematodes, while the lowest period was recorded when the individuals fed on parasitic nematodes at $35^{\circ} \mathrm{C}$ (10.1 days).

\section{Longevity}

Statistical analysis of current data in Table (3), pointed out that male adulthood was significantly differed. It was $(82.65,76.3),(72.45,68.2)$ and $(66.4$ and 60.0 ) days when reared at 15,25 and $35^{\circ} \mathrm{C}$, and fed on free and parasitic nematodes, respectively.

\section{Life span}

Accordingly, the life span of the mite, U. krantzi differed at different temperatures on different kinds of food. This period lasted the highest time (107.4 days) when the individuals fed on the free tested nematode at $15^{\circ} \mathrm{C}$, changed to recorded the lowest level of duration when mites reared at $35{ }^{\circ} \mathrm{C}$ (71.1 days) on parasitic nematodes, Table (3). 
The relationship between mites and nematodes was first reported by many authors allover the world. Since then, the work on mites and their possible influence on soil nematodes population remained very limited. Several species of family Uropodidae were recorded feeding on vermiform nematodes. The most definite association between mites and nematodes came from the work of Abou-El-Nagga et. al., (1987) who studied the biological aspects of the uropodid mite, Chiropturopoda bakeri Zaher \& Afifi when fed on nematodes as a natural food. Also, Rodriguez et. al., (1972) cultured Macrocheles muscaedomesticae (Scopoli) on Rhabditis sp., and found it to prefer house fly eggs over nematodes. Its prot-and deutero-nymphs under same conditions, however, preferred nematodes.Imbriani and Mankau (1983) observed voracious feeding by a mesostigmatid mite Lasioseius sculpatus Kennett on Aphelenchus avenae Bastian and Cephalobous sp. In culture, increased population of mite resulted in a significant decline of $A$. avenae. Bilgrami (1994) reported that Tyrophagus putrescentiae (Schrank) is predacous on many species of plant and soil nematodes belonging to three trophic categories viz., saprophagous, plant parasitic and predacous nematodes. Mites preferred second-stage juveniles of plant parasitic nematodes but predacous nematodes resisted predation comparatively better than others. Food preference and some biological aspects of uropodid mite, Aegyptus zaheri n. sp. were studied by using different types of food (acrid mite, Rhizoglyphus sp. yeast, sugarcane, and entomopathogenic nematode, (Heterorhabditis bacterophora), Abdel-Ghany (2009).The obtained results indicated that yeast and the acarid mite reduced the development duration of the adult. Female life cycle averaged 28.6 and 28.9 days on yeast and acarid mite, respectively. The author noticed also that, the dult females deposited eggs only when fed on yeast. Generally, the use of some predacious mites in controlling plant parasitic nematodes were previous studies by several researchers (Mankau, 1980, and El-Hady and El-Naggar (2001). These studies showed a considerable reduction in nematode population by using some predacious mite species belonging mainly gamasid mites. Finally, it can be concluded that prey species greatly affected the duration of the development, longevity and fecundity of uropodid mite, U.krantzi. 


\section{REFERENCES}

1. Abbassy, M. A., S. A. Montasser, M. H. Abd Allah and M. H. Mowafi 1991. The ability of two uropodid mites to feed and develop on free-living nematodes.AlAzher J. Agric. Res., 13: 237-246.

2. Abdel-Ghany, D. M. A. 2009. Taxonomical and biological studies on mites associated with some insects of agricultural economic importance. Fac. Agric. Ain Shams Univ., Egypt, 147 pp.

3. Abou-El-Naga, M.A., H.A. Taha and A.B. Abou-El-Sooud. 1987. Neamtodes as a natural food for Chiropturopoda bakeri Zaher \& Afifi (Acarina: Uropodidae). Zagazig J.Agric. Res., 14 (2): 660-672.

4. Abou-El-Sooud, A. B. 1992.Ecological and taxonomical studies on nematodes in certain Governorates of Egypt. Ph.D.Thesis, Fac.Agric.Al-Azhar Univ., 252 pp.

5. Afifi, A. M. 1980. Occurrence of mites in different organic manures. Ph. D. Thesis, Fac. Agric. Cairo Univ., 202 pp.

6. Bilgrami, A. L. 1994. Predatory behaviour of a nematode feeding mite, (Tyrophagus putrescentiae) (Sarcoptiformes: Acaridae). Fudam. Appl. Neamtol. 17 (4):293-297.

7. Duncan, D. B. 1955. Multiple range $F$ test. Biometrics, 11:1-14.

8. El-Bishlawy, S. M. and A. M. Afifi. 1982. Life history of fungivorous mite, Trichouropoda patavina (Canestrini) (Acari: Gamasida: Uropodidae). Proc. Egypt's National Conf. / Ent. Dec., 1: 15-24.

9. El-Hady, M. M and H. I. El-Naggar. 2001. Possibility of the control of the root-knot nematode Maloidogyne incognita on sunflower plants by certain predacious mites.J. Agric. Sci. Mansoura Univ., 26 (4): 2307-2311.

10. Imbriani, J. I. and R. Mankau. 1983. Studies on Lasioseius sculpatus, a mesostigmatid mite predaceous on nematodes. J. Nematology, 15: $523-528$.

11. Karg, V. W. 1961. Okologisch Untersuchungen von edaphischen Gamasiden (Acarina: Parasitiformes). Pediobiologia, 1: 77-98.

12. Krantz, G. W. 1978. A Manual of Acarology. Oregon State Univ. Book Stores, Inc., Corvallis, Oregon, 335p.

13. Mankau, R. 1980. Biological control of nematodes pests by natural enemies. Ann. Rev. Phytopathol., 18: 415-440

14. Metwally, A. M., M. Abou El-Naga and G. A. Ibrahim. 1983. Biological studies on Hypoaspis miles (B.) (Acarina: Laelapidae). Proc. 5th Arab Pesticides Conf., Tanta Univ., Egypt, 3: 336-346. 
15. Mowafi, M. H. 2005. Biological studies and feeding habits of the mite species Chiropturopoda bakeri Zaher and Afifi (Acarina: Uropodidae). Egyptian Journal of Biological Control,15 (2):97-98.

16. Nawar. M. S., G. M. Shereef and M. A. Ahmed. 1993. Effect of food on development, reproduction and survival of Chiropturopoda bakeri (Acarina: Uropodidae).Exp. \&Appl.Acarology, 17:277-281.

17. Radinovsky, S. 1965. The biology and ecology of granary mites of Pacific Northwest. III. Life history and development of Leiodinychus krameri (Acarina: Uropodidae). Ann, Ent. Soc. Amer.58: 259-267.

18. Radinovsky, S. and G.W. Krantz. 1961. The biology and ecology of granary mites of the Pacific Northwest. II. Techniques for laboratory observations and rearing. Ann. Ent. Soc. Amer., 54: 512-518.

19. Rodriguez, T. G., C. F. Wade and C. N. Wells. 1972. Nematodes as natural food for Macrocheles muscaedomesticae (Acarina: Macrochelidae) a predator of the house fly egg. Ann. Ent. Soc. Amer., 55: 507-511.

20. Sardar, M. A. and P.W. Murphy. 1987. Feeding tests of grass land soil inhabiting Gamasina predators. Acarologia, 28 (2): 117-121. 
تأثير اغذية مختلفة على تطور وتكاثر وحياة الاكاروس

\section{Uroobovilla krantzi Zaher and Afifi (Acarina: Uropodidae)}

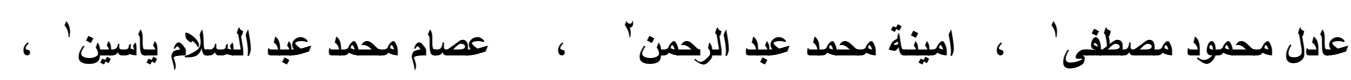
رانيا حمدى صابر' عمد لردن

$$
\begin{aligned}
& 1 \text { - معهد بحوث وقاية النباتات - مركز البحوث الزراعبة - الدقى - جيزة - مصر. }
\end{aligned}
$$

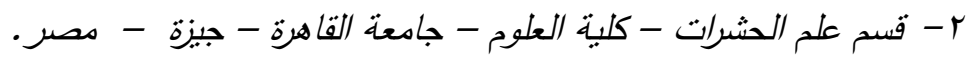

اجريت هذه الدراسـة تحت الظروف المعطلية لدراسـة تأثنيرنوعين مـن النيمـاتودا (الحرة المعيشـة و

المنطفلة على النبات) على المظاهر البيولوجية للاكاروس Uroobovilla krantzi عند درجات حرارة 10

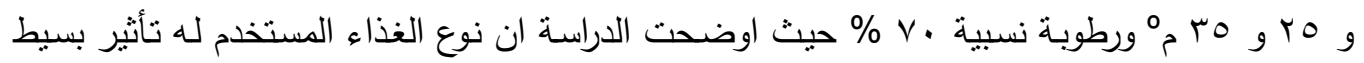

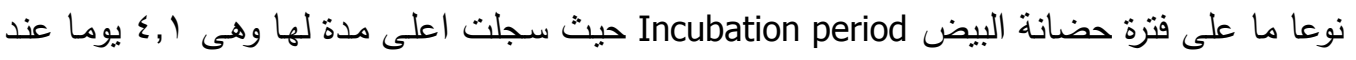

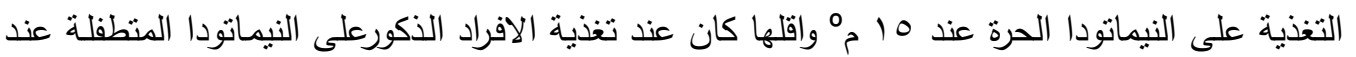

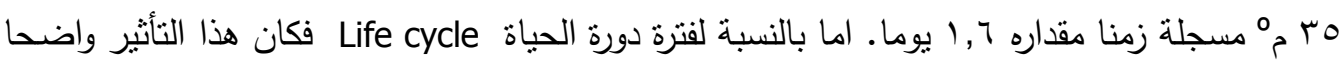

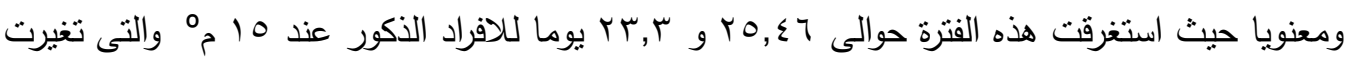

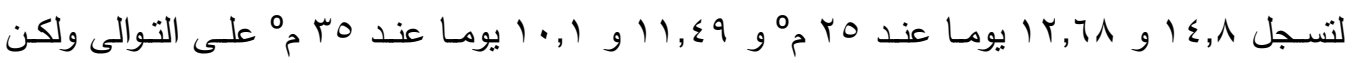

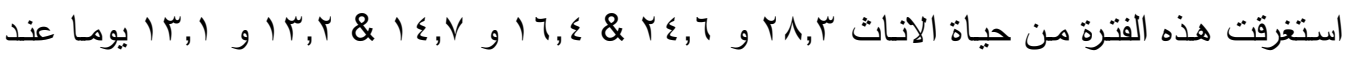

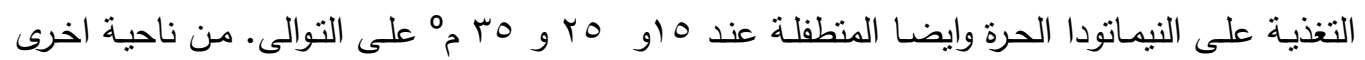

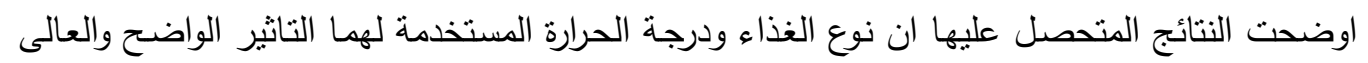

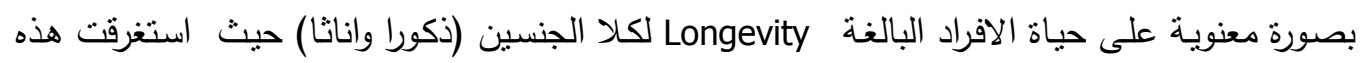
القترة زمنا مقداره

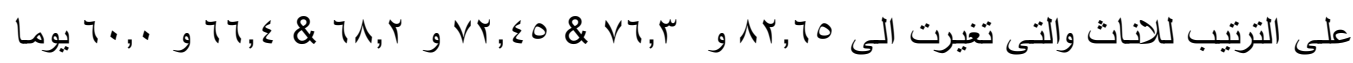
للافراد الذكور على الترنيب. واثتتت الدراسة ايضا ان الانثى تضع بيضا شريطة عملية التزاوج وكان لنوع

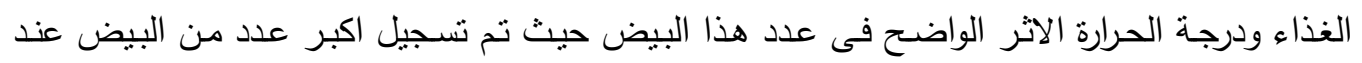

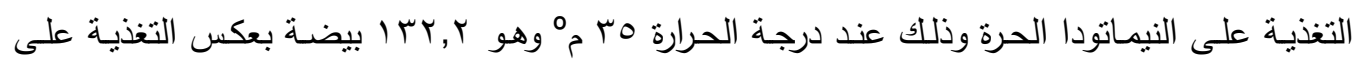
النيماتودا المتطفلة نباتيا عند 10 م والتى ادت الى وضع اقل عدد من البيض لهذا الاكاروس مسجلة 